\title{
Pendampingan dan Penguatan UMKM Desa Kenongo Melalui Branding dan Legalitas Produk Di Masa Pandemi Covid-19
}

\author{
Santi Rahma Dewi, Sriyono, Sumartik \\ Universitas Muhammadiyah Sidoarjo \\ e-mail: santirahma.d@umsida.ac.id, sriyono@umsida.ac.id, sumartik@umsida.ac.id
}

Diterima: April 2021 | Dipublikasikan: Juni 2021

\begin{abstract}
ABSTRAK
Desa Kenongo Kecamatan Tulangan Kabupaten Sidoarjo, merupakan salah satu desa di wilayah Sidoarjo yang memiliki banyak anggota UMKM. Dari hasil pemetaan awal jumlah UMKM di Desa Kenongo adalah 210 dengan berbagai macam jenis usaha. Jenis usaha yang ada adalah konveksi, batik, souvenir, makanan dan minuman, serta berbagai macam kerajinan tangan lainnya. Dengan jumlah UMKM yang cukup banyak ini, masih sangat sedikit yang mempunyai legalitas usaha serta kemampuan untuk membranding usahanya.Tujuan pendampingan ini adalah mewujudkan UMKM yang memiliki kualitas bagus dan dapat bersaing serta bertahan di masa pandemi dengan cara 1) Branding produk melalui media sosial serta memberikan keahlian agar dapat membuat sendiri media pemasaran. Selanjutnya yang 2) Legalitas usaha bagi UMKM agar lebih berkualitas dan terpercaya.Hasil pendampingan ini adalah meningkatnya nilai penjualan meskipun belum sama seperti sebelum pandemi, dan meningkatnya kesadaran pemilik UMKM untuk legalitas usahanya. Pendampingan ini juga membentuk kelompok UMKM dengan struktur baru yang lebih terorganisir untuk membantu pelaku UMKM dalam pengembangan usahanya. Pendampingan akan berkelanjutan di tahun kedua dan ketiga yaitu inovasi produk serta pengelolaan keuangan.
\end{abstract}

Kata Kunci: branding produk, legalitas, pandemi

\begin{abstract}
Kenongo Village, Tulangan District, Sidoarjo Regency, is one of the villages in the Sidoarjo area that has many MSME members. From the results of the initial mapping, the number of MSMEs in Kenongo Village is 210 with various types of businesses. The types of businesses that exist are convection, batik, souvenirs, food and beverages, as well as various other handicrafts. With this large number of MSMEs, there are still very few who have business legality and the ability to market their businesses. The purpose of this assistance is to realize MSMEs that have good quality and can compete and survive during the pandemic by 1) Branding products through social media and providing expertise so that they can create their own marketing media. Furthermore, 2) Business legality for MSMEs to be more qualified and reliable. The results of this assistance are an increase in the value of sales even though it is not the same as before the pandemic, and increased awareness of MSME owners for the legality of their business. This assistance also forms a group of MSMEs with a new, more organized structure to assist MSME actors in developing their business. The mentoring will continue in the second and third years, namely product innovation and financial management.
\end{abstract}

Keywords: product branding, legality, pandemic

\section{PENDAHULUAN}

UMKM atau usaha mikro kecil dan menengah dalam sejarah Indonesia memiliki peranan besar bagi perekonomian. Terbukti saat Indonesia mengalami krisis ekonomi pada 1998, di mana banyak perusahaan besar mengalami kebangkrutan, UMKM malah menjadi tulang punggung perekonomian pada masa itu. Badan Pusat Statistik atau BPS mencatat, penyerapan tenaga kerja tahun 1997 oleh usaha kecil saat itu menjadi yang tertinggi hingga 57,40 juta atau 87,62\%. Pada tahun 1998, saat inflasi berada di angka $88 \%$, defisit $13 \%$ dan cadangan devisa kurang US $\$ 17$ miliar, sektor usaha kecil mikro tetap mampu bertahan. Bertahannya usaha mikro kecil dan menengah saat krisis moneter terjadi karena saat itu bahan bakunya berorientasi pada ekspor. Sehingga, adanya kenaikan harga komoditas di pasar internasional malah menjadi keuntungan 
sendiri bagi pengusaha kecil saat itu.Mayoritas UMKM saat itu juga tidak bergantung pada modal bank. , saat sektor perbankan terpuruk, otomatis tidak berpengaruh besar pada usaha kecil.

Secara umum, pengertian UMKM adalah usaha perdagangan yang pengelolaannya dilakukan oleh perorangan atau badan usaha dengan lingkup kecil atau mikro.Sedangkan para ahli mendefinisikan usaha mikro kecil dan menengah sebagai usaha kecil yang menjadi sarana bantuan untuk meningkatkan perekonomian bangsa.

Melalui UU No. 20 Tahun 2008 tentang UMKM, persoalan seperti akses permodalan usaha kecil mikro dan menengah ke lembaga keuangan jadi teratasi. Selain itu regulasi ini menjelaskan kewajiban pemerintah dalam menciptakan perkembangan UMKM menjadi lebih baik lagi. Selain itu, ada beberapa regulasi lain yang dibuat untuk melindungi UMKM, seperti : 1) Peraturan Presiden Nomor 98 Tahun 2014 yang mengatur tentang kepemilikan surat izin usaha sebagai bukti pengesahan dan legalitas dari pemerintah., 2) PP Nomor 23 Tahun 2018 yang mengatur pelanggaran pajak yang dikeluarkan oleh pelaku UMKM. Regulasi ini juga menjelaskan besaran pajak didasarkan atas penghasilan dari usaha yang diterima perusahaan melalui peredaran bruto tertentu., 3) Peraturan Menteri Perekonomian Nomor 11 Tahun 2017 terkait pendanaan modal usaha untuk usaha mikro kecil dan menengah.

Dilihat dari perkembangan UMKM di Indonesia, usaha ini mampu bertahan di tengah krisis ekonomi. Bahkan, usaha kecil ini menjadi andalan penyerapan tenaga kerja, dikuatkan dengan data BPS. Harapan ini pun terus dikuatkan pemerintah di saat pandemi seperti sekarang, untuk pemulihan kondisi ekonomi yang ikut terimbas.

Perlu dicermati dalam pendampingan UMKM ini adalah kekuatan dan kelemahan UMKM, dimana kekuatan UMKM adalah mampu menyerap tenaga kerja dan bertahan dari keterpurukan ekonomi, pemilik usaha bebas bertindak atau dalam mengambil keputusan, pemilik usaha turun tangan langsung dalam menjalankan bisnisnya, usaha yang dijalankan sesuai dengan kebutuhan masyarakat setempat. Sedangkan kelemahannya adalah jumlah modal yang terbatas menjadi faktor penghambat pemilik usaha mengembangkan bisnisnya adalah gaji yang ditawarkan kecil sehingga kurang diminati pencari kerja, dalam menjual produknya tidak konsisten dan bisa berganti-ganti, sehingga lemah dalam spesialisasi.

Berdasarkan atas kelemahan dan kelebihan UMKM seperti yang disebut diatas, maka langkah-langkah dalam pendampingan UMKM adalah dengan memetakan masalah dan kendala yang dialami oleh masing-masing UMKM di wilayah desa Kenongo Kabupaten Sidoarjo. Dengan memetakan UMKM yang ada maka langkah selanjutnya adalah melalui sosialisasi terhadap regulasi yang ada untuk mendapatkan legalitas. Agar usaha lebih berkembang harus memiliki dan memproduksi produk secara kontinyu dan didukung dengan pemasaran yang baik

Terutama di wilayah Kabupaten Sidoarjo yang merupakan kota UMKM dengan jumlah UMKM mencapai 216.000 yang cukup banyak menyerap tenaga kerja, sehingga membantu peningkatan kesejahteraan masyarakat di sekitarnya. Salah satu desa di Sidoarjo yang menyumbang cukup banyak UMKM adalah Desa Kenongo Kecamatan Tulangan Kabupaten Sidoarjo. Di desa Kenongo ini memiliki cukup banyak UMKM yaitu 200 lebih, dimana banyak diantaranya merupakan usaha pemula.

UKM Desa Kenongo dalam pengembangannya dapat dibagai dalam beberapa skema, yaitu:

a. Pendampingan Legalitas Usaha

Dalam langkah awal setelah dilakukan pemetaan, UKM harus didampingi agar memiliki lagalitas awal yang akan memberikan jalan untuk perijinan selanjutnya. Minimal adalah Surat Keterangan Usaha (SKU) yang dikeluarkan oleh kepala desa. Selanjutnya setelah memperbaiki kualitas produk dapat meningkatkan legalitas pada produknya yaitu P-IRT dan Halal

b. Pendampingan Peningkatan Kualitas Produk

Selanjutnya diperlukan peningkatan kualitas produk, yaitu dengan :Mendapatkan bahan baku yang tepat harga, jumlah dan kualitasMenciptakan produk yang memiliki kekhasan,Pendampingan pengurusan P-IRT (untuk produk hasil olahan) dan halal. 
Informasi dari koordinator UKM Desa Kenongo, bahwa pelaku UKM Desa Kenongo masih sangat minim pengetahuan tentang legalitas, kualitas produk, pemasaran dan pegelolaan keuangan hal ini didukung dari minimnya pengtehuan tentang tehnologi informasi yang dapat dimanfaatkan untuk pengembangan dan pengelolaan UKM

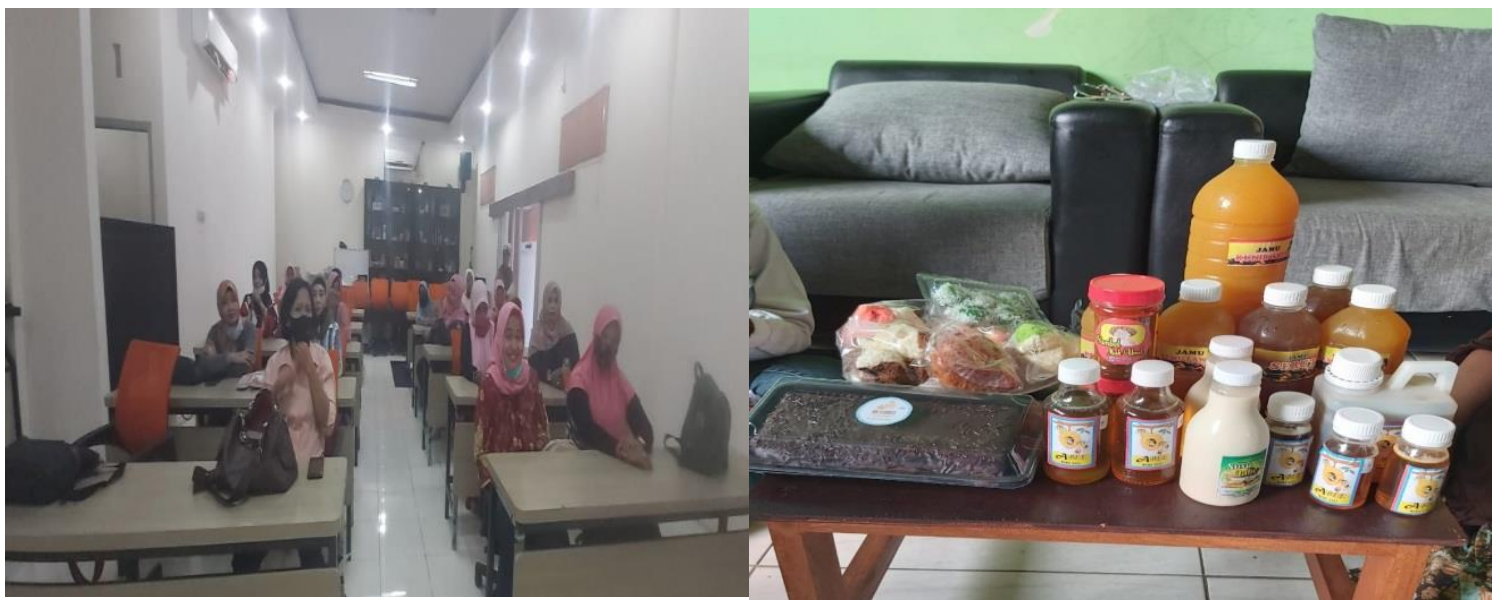

Gambar 1.1.Kegiatan dan Produk UKM Desa Kenongo

Kondisi UKM Desa Kenongo seperti yang tampak pada gambar tersebut diatas. Dalam hal produk dan kemasan yang masih sangat terbatas dan sederhana. Sehingga perlu dilakukan pendampingan atas produk dan kemasannya. UKM Desa Kenongo yang belum memiliki legalitas Dan terakhir dalam pengelolaan keuangan belum melaksanakan sistem pencatatan akuntansi secara manual, yang dilakukan masih menggabungkan keuangan pribadi dengan keuangan usaha sehingga tidak bisa mengukur laba yang didapatkan. Dari pemaparan tersebut di atas, maka ada beberapa permasalahan mitra yang harus segera dipecahkan adalah: 1) Mitra belum memiliki legalitas usaha dan produk, 2) Mitra belum memiliki kemasan dan kualitas produk yang baik, serta pemasaran yang baik (branding produk)

Kegiatan pendampingan yang telah dilaksanakan oleh tim salah satunya adalah di desa wisata Sumbergedang, dimana permasalahan utama yang dihadapi hampir sama yaitu belum adanya legalitas produk, belum melakukan pemasaran secara online serta belum melakukan pencatataan dan pelaporan keuangan dengan baik dan benar serta belum terotomasi. Sehingga dilakukan pendampingan secara menyuluruh pada tata kelola manajemennya, produk, pemasaran dan keuangan dengan hasil cukup memuaskan lebih tertata kelola majemen dan keuangannya begitupula dengan pemasaran. Dengan hasil dari pengabdian terdahulu maka untuk UKM Desa Kenongo yang memiliki masalah yang cukup komplek, tim pusat studi ekonomi dan bisnis yang berlatar belakang dosen dengan kompetensi di bidang ekonomi yaitu pemasaran, manejemen, keuangan dan akuntansi mencoba membantu UKM Desa Kenongo agar segala kendala dan masalah yang dihadapi mendapatkan solusinya. Sehingga dharapkan seluruh UKM Desa Kenongo maju dan berkembang, selanjutnya dapat lebih banyak menyerap tenaga kerja dan meningkatkan kesejahteraan masyarakat sekitarnya.

\section{METODE PEIAKSANAAN}

Metode pelaksanaan dari kegiatan PKM ini adalah dengan menggunakan metode PALS (Participatory Action Learning System), dimana metode ini pada dasarnya adalah pelibatan mitra dalam proses pembelajaran aktif partisipasi dalam program aksi penerapan pelaporan keuangan khususnya akuntansi untuk pengembangan UKM Desa Kenongo, legalitas usaha dan produk. Inovasi produk,kemasan dan branding, mem-branding produk menggunakan strategi marketing terkini sehingga membentuk suatu sistem interaksi pembelajaran masyarakat secara partisipatif, baik secara personal maupun komunal. 
Kegiatan pendampingan ini dilaksanakan melakukan pemetaan terhadap kebutuhan masing-masing UKM dilanjutkan dengan pendampingan untuk mendapatkan legalitas usaha maupun legalitas untuk produknya. Selanjutnya dengan memberikan pengetahuan tentang branding produk maupun branding terhadap usahanya.

Secara diagramatik permasalahan dan solusi untuk mitra dapat digambarkan sebagai berikut:

\begin{tabular}{|c|c|c|c|}
\hline $\begin{array}{l}\text { Penggalian } \\
\text { informasi : } \\
\text { - } \\
\text { mengunjungi } \\
\text { lokasi dan } \\
\text { melakukan } \\
\text { wawancara } \\
\text { dengan } \\
\text { Koordinator } \\
\text { UKM Desa } \\
\text { Kenongo }\end{array}$ & $\begin{array}{l}\text { Memahami } \\
\text { permasalahan } \\
\text { : } \\
\text { Kelemahan } \\
\text { UKM Desa } \\
\text { Kenongo } \\
\text { - -Produk dan } \\
\text { usaha belum } \\
\text { memiliki } \\
\text { legalitas } \\
\text { - -Belum } \\
\text { memiliki } \\
\text { strategi } \\
\text { pemasaran }\end{array}$ & $\begin{array}{l}\text { Analisis } \\
\text { solusi } \\
\text { permasalaha } \\
\text { n } \\
\text { Pendamping } \\
\text { an legalitas } \\
\text { Pendamping } \\
\text { an Inovasi } \\
\text { Produk dan } \\
\text { kemasan }\end{array}$ & $\begin{array}{l}\text { Implementasi } \\
\text { Solusi } \\
\text { Memberikan } \\
\text { sosialisasi dan } \\
\text { pendampingan } \\
\text { legalitas } \\
\text { Pendampingan } \\
\text { pemasaran dan } \\
\text { branding } \\
\text { produk secara } \\
\text { online }\end{array}$ \\
\hline
\end{tabular}

Gambar Prosedur kerja pelaksanaan metode pemecahan masalah

\section{HASIL KEGIATAN}

Berdasarkan permasalahan mitra diatas, maka solusi yang ditawarkan untuk tahun pertama adalah melakukan branding produk dari masing-masing UMKM serta melakukan dan sosialisasi legalitas untuk UMKM yang sudah memenuhi syarat. Kegiatan yang dilakukan di awal adalah melakukan pemetaan terhadap UMKM yang ada di Desa Kenongo, dengan hasil pemetaan terdapat 210 UMKM dengan berbagai jenis usaha mulai dari batik, konveksi, aneka kerajinan tangan, makanan dan minuman.

\section{A. Branding Produk dan Usaha}

Produk UKM seringkali kalah saing dengan produk perusahaan dalam pasar yang sangat kompetitif. Padahal secara kualitas dan nilai produk, tidak jauh berbeda atau bahkan lebih baik dari produk perusahaan. Hal ini bisa terjadi akibat dari branding perusahaan yang bagus dan UKM hingga saat ini masih banyak yang belum memahami pentingnya branding untuk produk yang mereka jual. Sehingga, tidak jarang pelaku UKM yang mengesampingkannya. Ketika mendapati produk suatu UKM dari warung atau toko, tidak jarang brand identity dari produk tersebut kurang kuat, misalnya dari sisi packaging masih terkesan polos dan kurang menarik. Terkadang malah tidak mencantumkan alamat produksi. Padahal dalam penjualan produk, branding merupakan hal penting yang menjadi faktor bagi kesuksesan usaha. Maka dari itu, jika ingin memenangkan pasar, pelaku UKM dituntut untuk melakukan branding yang kuat pada produk mereka agar memiliki nilai jual yang baik. Untuk itu, beberapa cara dilakukan agar UKM Desa Kenongo memiliki branding yang kuat, antara lain:. 


\section{Membangun Identitas yang Otentik}

Kunci dari suatu branding yaitu dapat menciptakan produk yang berbeda dengan kompetitor. Oleh karena itu, harus membuat identitas yang otentik untuk produk juga usaha bagi pelaku UKM Desa Kenongo agar tidak serupa dengan milik kompetitor. Selain itu juga harus bisa membuat konsumen mengingat brand yang kita miliki pertama kali ketika mereka membutuhkan produk terkait. Branding yang otentik bisa membawa usaha cepat dikenal, sehingga mudah berkembang secara luas. Dengan branding yang kuat, identitas bisnis yang diciptakan pun semakin baik. Dengan demikian, target pasar akan berebut untuk bisa mendapatkan produk UKM di masa mendatang. Sehingga tidak perlu repot-repot menawarkan produk dengan berbagai cara yang menguras biaya.

\section{Pentingnya Memperhatikan Komponen-komponen Kecil dalam Branding}

Menyisipkan hal-hal kecil dalam branding yang mungkin dianggap tidak terlalu penting, biasanya malah bisa mendorong produk UKM menjadi semakin luar biasa. Sebagai contoh, harus mempertimbangkan desain packaging, menentukan desain dan warna logo, menciptakan tagline, dan sebagainya. Komponen-komponen kecil yang tidak begitu terlihat nantinya akan membantu dalam membangun brand yang kuat. Sehingga sangat perlu mempertimbangkan hal-hal yang demikian untuk mengambil keputusan.

\section{Membangun Ruang Produksi Terbuka}

Menciptakan brand yang dapat diterima masyarakat secara luas merupakan salah satu strategi pemasaran yang tepat untuk dilakukan pada bisnis UKM. Strategi tersebut sangat efektif untuk membangun identitas produk terhadap konsumen dan menunjukkan keaslian bisnis bahwa produk yang dijual memang benar-benar diproduksi sendiri. Selanjutnya, juga dapat berupaya menciptakan tempat produksi terbuka yang bisa memberikan pengetahuan dan informasi secara langsung kepada pelanggan.

Jika telah berhasil mendorong konsumen untuk melakukan transaksi, maka selanjutnya harus mengupayakan kemudahan transaksi yang akan mereka lakukan.Perlu memikirkan sistem transaksi yang bisa langsung dilakukan melalui website. Hal ini ditujukan agar calon pembeli dapat langsung membayar pesanannya saat itu juga. Untuk mengakomodasi penerimaan pembayaran melalui berbagai metode, perlu menggunakan layanan payment gateway.

Fungsi dari payment gateway bisnis adalah untuk mengintegrasi berbagai metode pembayaran yang dilakukan oleh pembeli. Metode pembayaran yang dapat digunakan pembeli yaitu melalui transfer bank, kartu kredit, virtual account, maupun retail outlet seperti Alfamart. Jadi pembeli dari berbagai kalangan bisa melakukan transaksi dengan mudah untuk membeli produk.

Kegiatan branding produk ini telah diawali dengan perbaikan packaging serta membuat foto produk untuk membuat iklan di media sosial.

\section{B. Legalitas}

Selanjutnya untuk lebih meningkatakn kepercayaan konsumen terhadap produk dan usaha pelaku UKM, maka diperlukan legalitas produk maupun usahanya. Dari 210 UMKM yang tercatat baru 13 UMKM yang memiliki legalitas produk. Pendampingan legalitas masih dalam proses pendataan untuk UMKM yang bersedia mengurus legalitas. Kegiatan ini bekerja sama dengan dinas koperasi untuk sosialisasi legalitas usaha, dilaksanakan awal februari 2021. Legalitas penting untuk dipenuhi karena: 


\section{Menjadi badan usaha yang lebih kredibel (lebih mudah dipercaya oleh berbagai pihak)}

Contohnya, kalau belum punya izin lalu ke bank, mungkin hanya bisa akses pinjaman sampai Rp 20 juta. Sementara untuk buka cabang baru, misalnya, kita butuh Rp 150 juta. Untuk jumlah tersebut bank biasanya minta kelengkapan perizinan, sesederhana Surat Keterangan Domisili Usaha (SKDU) atau Surat Keterangan Usaha, atau Surat Izin Usaha Perdagangan (SIUP), atau Tanda Daftar Usaha Pariwisata (TDUP) Restoran. Hal ini karena yang memberi pinjaman mulai merasa perlu berhati-hati dan menekan resiko.

\section{Memperluas akses-akses peluang pengembangan usaha}

Ada beberapa asosiasi usaha tertentu - yang spesifik industri biasanya - meminta anggotanya mengumpulkan bukti-bukti perizinan usaha. Jika tidak, suatu usaha akan ditolak sebagai anggota. Banyak juga peluang-peluang tender atau kompetisi pengadaan di dinas-dinas, kantor-kantor, atau perusahaan-perusahaan yang juga mensyaratkan vendor memiliki perizinan lengkap. Tidak punya izin, sesederhana tidak punya NPWP, bisa terhindar dari peluang-peluang tersebut.

3. Secara internal, menambah rasa percaya diri pemilik/pengelola usaha dalam memasarkan produk/layanannya

Jangan anggap remeh dampak positif memiliki perizinan bagi internal tim. Contohnya,sebuah usaha Jus, setelah punya sertifikat halal MUI dan PIRT - pelaku usahanya semakin percaya diri memperkenalkan produk ke banyak kalangan.

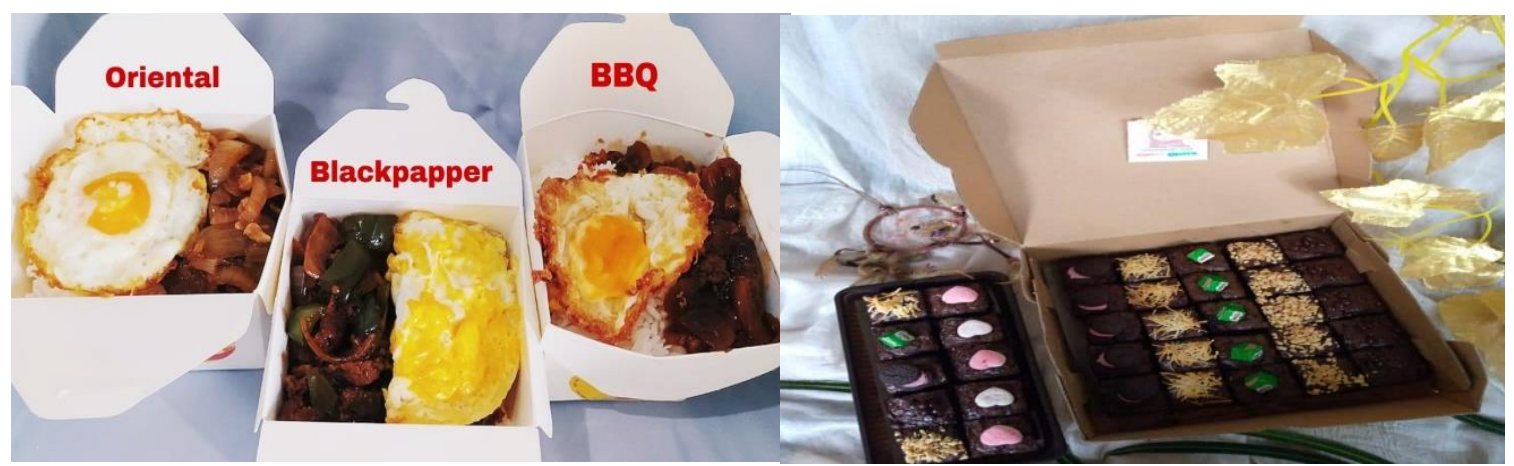

Gambar Produk UKM Desa Kenongo

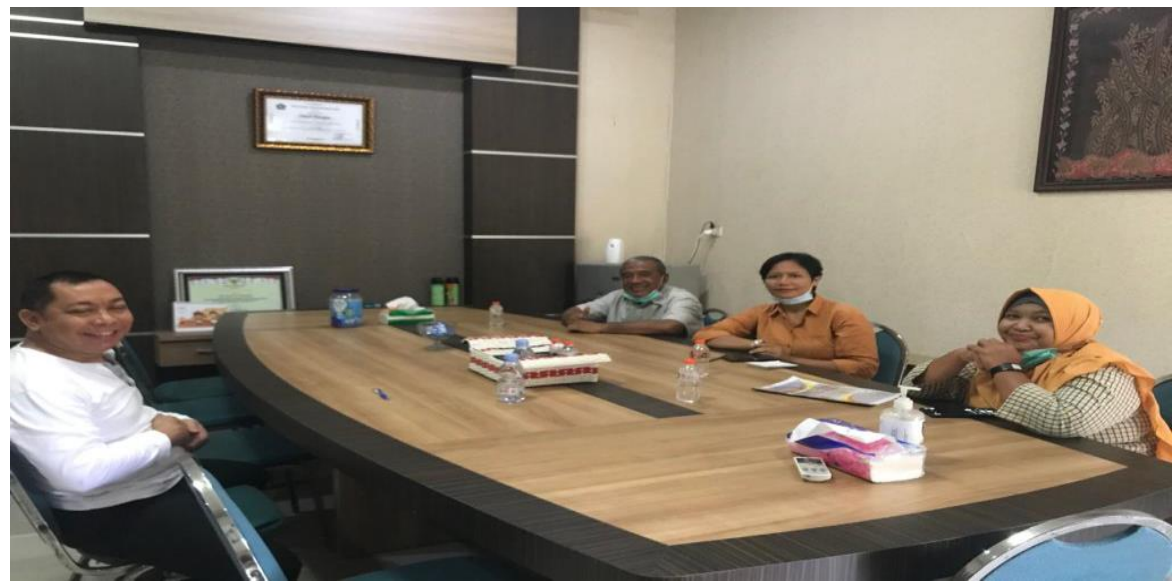

Pertemuan dengan Camat Tulangan untuk pendampingan Legalitas UMKM 


\section{KESIMPULAN DAN SARAN}

Berdasarkan hasil dari pendampingan kepada pelaku UMKM Desa Kenongo maka kami menarik kesimpulan yaitu peningkatan omzet dari tiap-tiap pelaku UMKM sangat dipengaruhi dari branding produk dan usaha yang dilakukan untuk lebih menarik dan meningkatkan permintaan konsumen, serta pentingnya legalitas produk serta usahanya untuk lebih meningkatkan kepercayaan konsumen serta pihak yang berkepentingan seperti investor maupun kreditur.

Masih perlu sosialisasi dan pendampingan untuk legalitas, karena belum semua pelaku UKM di Desa Kenongo memahami pentingnya legalitas baik produk maupun usahanya, terlebih masih menganggap mahal biaya legalitas. Padahal jika telah memiliki legalitas, maka peluang untuk mengembangkan usahanya jadi lebih luas.Dari 210 anggota pelaku UKM Desa Kenongo baru 13 yang telah memiliki legalitas.

\section{DAFTAR PUSTAKA}

https://republikjatim.com/baca/bhs-umkm-sidoarjo-butuh-pendampingan-pemerintah-janganpersulit-perizinannya

https://media.neliti.com/media/publications/171737-ID-pemberdayaan-usaha-mikro-kecil-danmenen.pdf 